\title{
UNHASCRITICAS: 15 ANOS DE DIFUSÃO DO CONHECIMENTO CIENTÍFICO EM EDUCAÇÃO (1995-2010)
}

Com este número, nossa revista atinge uma década e meia de publicação. Além da versão impressa, desde 1999 é disponibilizada uma versão online para auxiliar na articulação entre os diferentes setores do processo editorial - autores, leitores, conselheiros e técnicos -, promovendo o acesso às principais informações, oferecendo textos integrais e resumos.

Ao longo desse tempo, diversos aprimoramentos foram introduzidos. No intuito de propiciar às pessoas cegas e deficientes visuais o acesso ao conhecimento, foram editadas, em caráter experimental, uma versão em Braille (volume 9) e outra versão em cd-rom (volumes 9 a 11). Com o advento de programas como Dos Vox (UFRJ) e similares, esse público passou a ter acesso facilitado pela versão online.

Para favorecer o intercâmbio com a comunidade internacional, foram acrescentados resumos em francês e espanhol, possibilitando uma circulação em quatro línguas e incrementando a indexação nacional e internacional. Cabe destacar que, a partir deste número 31, contamos com mais um indexador de impacto internacional. Trata-se do 'Sistema de Información Científica Red de Revistas Científicas de América Latina y el Caribe, España y Portugal', com sede na Universidad Autónoma del Estado de México. Sendo assim, hoje, nosso periódico está presente em sete bases de indexação no Brasil, na França e no México: BBE, BVE, Clase, Francis, Iresie, Latindex e Redalyc.

Completados 15 anos de circulação, Linhas Críticas vem atendendo aos critérios de qualidade editorial do Comitê Qualis (Anped e MEC) em seus eixos de normalização, publicação, circulação, autoria e gestão, e está avaliada como publicação B1. Ao longo desse período, dos 504 textos recebidos, 147 foram recusados e 48 continuam em avaliação. Publicaram-se três apresentações de dossiês, cinco homenagens, 26 resenhas de livros e 275 artigos científicos de 365 pesquisadores de 15 países: Alemanha, Argentina, Brasil, Canadá, Cuba, Espanha, Estados Unidos, França, Israel, Itália, México, Portugal, Rússia, Timor-Leste e Uruguai. Também divulgaram-se 27 editoriais.

Em 2010, visando tornar a leitura mais agradável, Linhas Críticas adotou formato maior $(24 \mathrm{~cm} \times 17 \mathrm{~cm})$ e novo layout.

No que tange especificamente à sua composição, este trigésimo primeiro número da revista contou com a participação de Catia Piccolo Viero Devechi e Wivian Weller como editoras convidadas para elaboração de um dossiê sobre hermenêutica, teoria crítica e educação, com textos de renomados pesquisadores alemães e brasileiros. Enquanto a Hermenêutica traz a perspectiva do interpretar e da produção de sentido, a Teoria Crítica traz o comportamento questionador das formas de dominação, se colocando como panoramas de pensamentos indispensáveis à auto-compreensão e à reestruturação do campo pedagógico.

Assim, Heinz-Hermann Krüger e Anne Schippling analisam o desenvolvimento do conceito de Ciência Crítica da Educação na Alemanha desde a década de 1960 e concluem que ela terá perspectiva no século 21 como ciência reflexiva e interdisciplinar. 
Baseado em Adorno e Habermas, Luiz Roberto Gomes relaciona a formação de pessoas emancipadas, críticas, não conformistas e participativas à vinculação entre educação e política.

Catia Piccolo Viero Devechi discute a racionalidade comunicativa de Habermas e a possibilidade de crítica e de objetividade na produção do conhecimento educacional empírico, comprometida com a prática coletiva.

Partindo da teoria de Honneth, Amarildo Luiz Trevisan e Noeli Dutra Rossatto apresentam o "reconhecimento prévio do outro" como uma condição não-epistêmica fundamental das pesquisas educacionais, para evitar a armadilha da reificação.

Wivian Weller investiga dois problemas recorrentes no desenvolvimento de metodologias qualitativas: o método e a prática de pesquisa. Para tanto, recorre à "hermenêutica objetiva" de Oevermann, vinculada à Teoria Crítica da Escola de Frankfurt.

Ainda sobre a utilização da "hermenêutica objetiva" na pesquisa educacional, Rita Amelia Teixeira Vilela e Juliane Noack-Napoles relatam suas dimensões em textos de pesquisas sobre escola e sala de aula na Alemanha e no Brasil.

A seção 'Outros Temas' inicia-se com uma investigação sobre a gestão pública e a educação ambiental em Curitiba (PR). Samira El Ghoz Leme e Maclovia Corrêa da Silva analisam matérias instrucionais como o Guia do Projeto Ecocidadão.

Uhelinton Fonseca Viana e Eda Maria de Oliveira Henriques refletem sobre cultura, patrimônio e educação, com base nos trabalhos de Jeudy, de Vigotski e da teoria crítica do currículo, buscando seu potencial para o processo ensino-aprendizagem.

Uma pesquisa-ação em turmas de $5^{\circ}$ e $6^{\circ}$ anos do ensino fundamental de uma escola pública conduzida por Lúcia Furtado de Mendonça Cyranka, Lívia Nascimento, Patricia Ribeiro e Simone Peron discute com os alunos a função da escola e da sociolinguística.

Hedioneia Pivetta, Dirce Backes, Adriana Carpes, Amara Battistel e Mara Marchiori refletem sobre a efetiva integração entre ensino, pesquisa e extensão universitária na formação de profissionais da saúde, por meio de um estudo de caso.

O desigual acesso ao ensino superior público catarinense de 1998 a 2007 - antes da implantação do programa de cotas para estudantes afrodescendentes e oriundos de escolas públicas - é desvelado por Ione Ribeiro Valle, Fernanda Barrichello e Juliane Tomasi.

Seguem duas resenhas de livros, elaboradas por Aquiles Santos Cerqueira (DF) e Maria Edith Romano Siems (RR). Os 31 consultores ad hoc que avaliaram artigos em 2010 são listados ao final.

Aos leitores comunico que este é o último fascículo em que participo como editor e agradeço aos que colaboraram com este projeto editorial, em particular Célio da Cunha, Ilma Passos Alencastro Veiga, Regina Vinhaes Gracindo e Walter Esteves Garcia, pela contribuição durante oito anos.

Desde 1998, exerci este ofício, acompanhando pesquisadores, docentes, estudantes e profissionais em suas buscas por acesso e difusão do conhecimento. No começo, a correspondência sobre os manuscritos era feita através de cartas. Com a implantação do Sistema Eletrônico de Editoração de Revistas (Seer) - programa canadense gratuito traduzido pelo Ibict para a gestão de uma publicação periódica -, as trocas postais serão, paulatinamente, substituídas pelo correio eletrônico.

À nova gestão de Linhas Críticas, votos de sucesso no enfrentamento dos futuros desafios da edição científica.

\section{Antônio Villar Marques de Sá Editor}

